\title{
Improved control of Septoria tritici blotch in durum wheat using cultivar mixtures
}

Article

Accepted Version

M'Barek, S. B., Karisto, P., Abdedayem, W., Laribi, M., Fakhfakh, M., Kouki, H., Mikaberidze, A. and Yahyaoui, A. (2020) Improved control of Septoria tritici blotch in durum wheat using cultivar mixtures. Plant Pathology, 69 (9). pp. 1655-1665. ISSN 0032-0862 doi: https://doi.org/10.1111/ppa.13247 Available at https://centaur.reading.ac.uk/91550/

It is advisable to refer to the publisher's version if you intend to cite from the work. See Guidance on citing.

To link to this article DOI: http://dx.doi.org/10.1111/ppa.13247

Publisher: Wiley-Blackwell

All outputs in CentAUR are protected by Intellectual Property Rights law, including copyright law. Copyright and IPR is retained by the creators or other copyright holders. Terms and conditions for use of this material are defined in the End User Agreement.

www.reading.ac.uk/centaur 
Central Archive at the University of Reading

Reading's research outputs online 


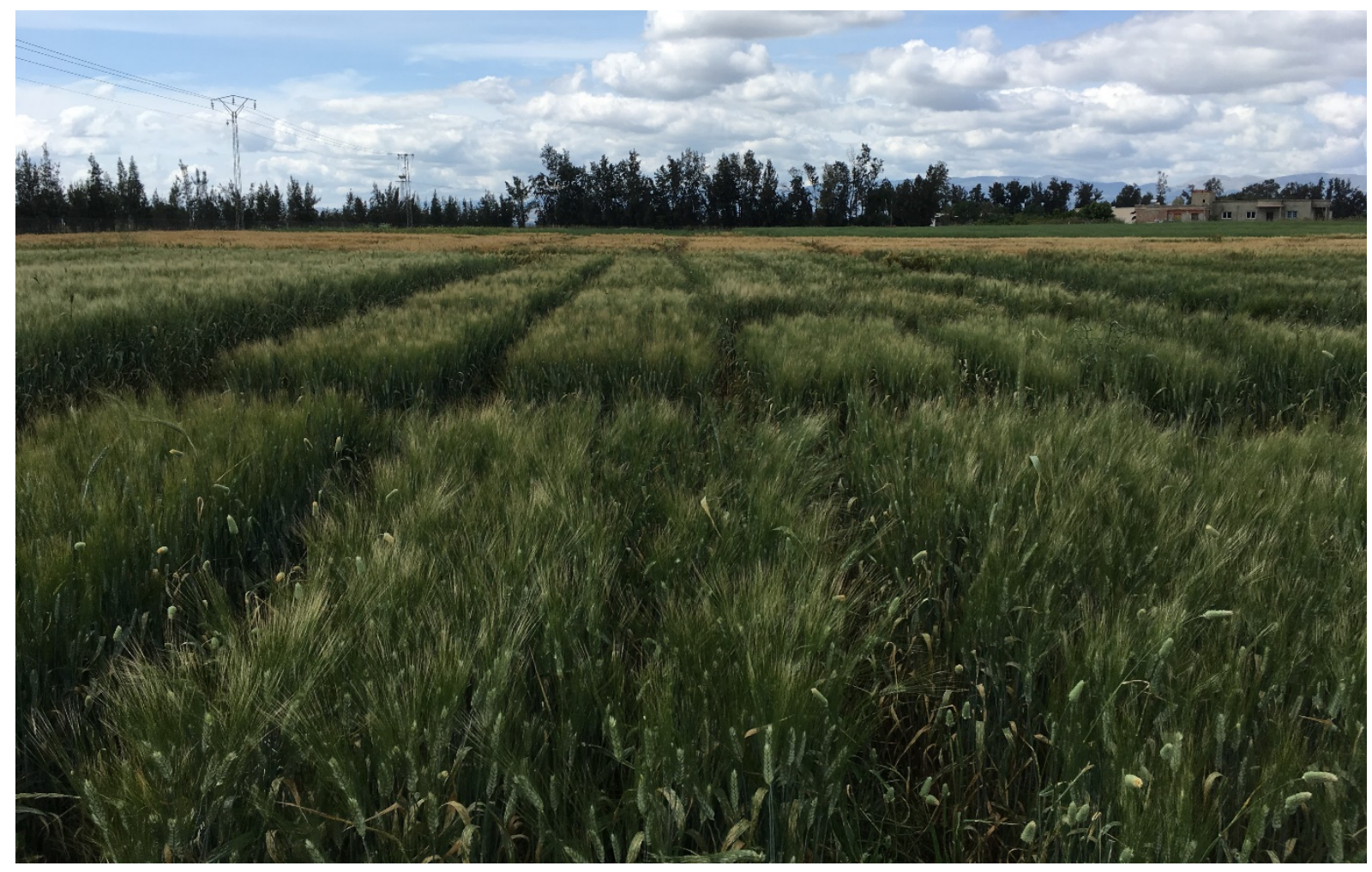

\section{Improved control of Septoria tritici blotch in durum wheat using cultivar mixtures}

S. Ben $M^{\prime} B^{B a r e k}{ }^{1,5 a}$, P. Karisto ${ }^{2 a}$, W. Abdedayem ${ }^{3,5}$, M. Laribi ${ }^{3,5}$, M. Fakhfakh ${ }^{4}$, H. Kouki ${ }^{5}$, A. Mikaberidze ${ }^{6 b}$, A. Yahyaoui ${ }^{5,7 b}$

a Joint first authors, ${ }^{b}$ joint last authors

${ }^{1}$ Regional Field Crops Research Center of Beja (CRRGC) BP 350, 9000 Beja, Tunisia.

2 Department of Evolutionary Biology and Environmental Studies, University of Zurich, Zurich, Switzerland.

${ }^{3}$ University of Carthage, National Agronomic Institute of Tunisia (INAT), Tunis, Tunisia.

${ }^{4}$ Comptoir Multiservices Agricoles, 82, Avenue Louis Brailles, Tunis Belvedre, Tunis, Tunisia.

${ }^{5}$ CRP Wheat Septoria Precision Phenotyping Platform, Tunis, Tunisia.

${ }^{6}$ School of Agriculture, Policy and Development, University of Reading, Whiteknights, Reading, UK.

${ }^{7}$ International Maize and Wheat Improvement Center (CIMMYT) km. 45 Carretera México-Veracruz El Batan, Texcoco, Estado de México, CP 56130.

Corresponding author: S. Ben M'Barek (sarrah bm@msn.com).

Running head: Cultivar mixtures for STB control

Keywords: variety mixtures, Zymoseptoria tritici, durum wheat, sustainable disease management 
Ben M'Barek, Karisto, Abdedayem, Laribi,

Cultivar mixtures for STB control Fakhfakh, Kouki, Mikaberidze, Yahyaoui

\section{Abstract}

Mixtures of cultivars with contrasting levels of disease resistance can suppress infectious diseases in wheat, as demonstrated in numerous field experiments. Most studies focused on airborne pathogens in bread wheat, while splash-dispersed pathogens have received less attention, and no studies have been conducted in durum wheat. We conducted a two-year field experiment in Tunisia, a major durum wheat producer in the Mediterranean region, to evaluate the performance of cultivar mixtures in controlling the polycyclic, splash-dispersed disease Septoria tritici blotch (STB) in durum wheat. To measure STB severity, we used a novel, high-throughput method based on digital analysis of images captured from 3074 infected leaves collected from 42 and 40 experimental plots on the first and the second year, respectively. This method allowed us to quantify pathogen reproduction on wheat leaves and to acquire a large dataset that exceeds previous studies with respect to accuracy and statistical power. Our analyses show that introducing only $25 \%$ of a disease-resistant cultivar into a pure stand of a susceptible cultivar provides a substantial reduction of almost $50 \%$ in disease severity. However, adding a second resistant cultivar to the mixture did not further improve disease control, contrary to predictions of epidemiological theory. Susceptible cultivars can be agronomically superior to resistant cultivars or be better accepted by growers for other reasons. Hence, if mixtures with only a moderate proportion of the resistant cultivar provide similar degree of disease control as resistant pure stands, as our analysis indicates, such mixtures are more likely to be accepted by growers. 
bioRxiv preprint doi: https://doi.org/10.1101/664078. this version posted April 15, 2020. The copyright holder for this preprint (which was not certified by peer review) is the author/funder. It is made available under a CC-BY 4.0 International license.

Ben M'Barek, Karisto, Abdedayem, Laribi, Cultivar mixtures for STB control Fakhfakh, Kouki, Mikaberidze, Yahyaoui

\section{Introduction}

Reduction of biodiversity due to human activities has been linked with increased outbreaks of pests and infectious diseases in wildlife and humans (King \& Lively 2012; Ostfeld \& Keesing 2012; Civitello et al., 2015). To counter that, a deliberate introduction of genetic diversity into crop plant populations is proposed as a promising way to suppress plant disease epidemics (Wolfe, 1985; Finckh et al., 2000; Mundt, 2002) and enhance the overall crop function (Newton et al., 2009). One way to diversify crop plants is to grow two or more genetically distinct cultivars of the same crop concurrently within the same field. This can be achieved by mixing seeds of different cultivars before sowing, thereby creating a physical cultivar mixture.

The idea behind cultivar mixtures is that genetic, physiological, structural, and phenological diversity among the components of the mixture (i.e., among different cultivars that comprise the mixture) may drive beneficial interactions not only between cultivars but also between cultivars and environments (Kiær et al., 2009; Newton et al., 2009; Borg et al., 2018). As a result, cultivar mixtures have proven to improve the resilience to biotic and abiotic stresses in crops and boost yield and its stability compared to pure stands, especially in low pesticide cropping systems (Kiær et al., 2009; Smithson and Lenné, 1996; Borg et al., 2018). Mixtures can also enhance product quality, if the components of the mixture are chosen appropriately (Finckh et al., 2000; Mundt, 2002). For these reasons, cultivation of cultivar mixtures has gained interest in several countries (Borg et al., 2018; de Vallavieille-Pope et al., 2006; Finckh \& Wolfe, 1997; Wolfe et al., 2008).

Cultivar mixtures suppress the development of disease epidemics when the mixture components have contrasting levels of resistance to the targeted disease (Wolfe, 1985; Finckh \& Wolfe, 2006; Gigot et al., 2013). Consequently, most studies investigated mixtures of disease-susceptible and disease-resistant cultivars (cf. Garrett \& Mundt, 1999, and Mikaberidze et al., 2015, for discussion on mixtures that contain two or more resistant cultivars). The most important mechanisms of disease reduction in cultivar mixtures are the dilution (or density) effect, the barrier effect, induced resistance (Wolfe, 1985; Finckh et al., 2000), and competition among pathogen strains (Garrett \& Mundt 1999). From an evolutionary perspective, appropriately designed mixtures are expected to hamper adaptation of the pathogen and increase the durability of the resistance genes deployed (Finckh et al., 2000; Mundt, 2002).

Many studies presented convincing empirical evidence that cultivar mixtures provide effective control of airborne cereal diseases, particularly rusts and mildews, as reviewed by Wolfe (1985), Finckh et al. (2000), and Mundt (2002). See also a meta-analysis of 11 publications on stripe (yellow) rust of wheat (Huang et al., 2012). However, effect of cultivar mixtures on splash-dispersed cereal 
bioRxiv preprint doi: https://doi.org/10.1101/664078. this version posted April 15, 2020. The copyright holder for this preprint (which was not certified by peer review) is the author/funder. It is made available under a CC-BY 4.0 International license.

Ben M'Barek, Karisto, Abdedayem, Laribi, Cultivar mixtures for STB control Fakhfakh, Kouki, Mikaberidze, Yahyaoui

diseases is less studied and the disease reduction by mixtures appears less consistent and is on average lower in magnitude compared to airborne diseases (Jeger et al., 1981b; Mundt et al., 1994; Newton et al., 1997; Garrett \& Mundt, 1999).

Here, we investigated Septoria tritici blotch (STB) disease, which is predominantly splash-dispersed. STB is one of the major threats to wheat production worldwide. It is caused by the fungal pathogen Zymoseptoria tritici. The infection cycle of the fungus starts when asexual pycnidiospores or airborne sexual ascospores land on a susceptible wheat leaf. The asymptomatic phase lasts for about 8-14 days. Karisto et al. (2019) observed an extreme asynchronicity in the duration of the asymptomatic phase: lesions appeared continuously during a period of up to 3 weeks, even when a single pathogen strain was used to infect a single host variety. The switch to necrotrophy leads to a collapse and death of the host mesophyll cells usually between 12 and 18 days after penetration (Kema et al., 1996; Duncan \& Howard, 2000; Steinberg, 2015). Within necrotic lesions, the fungus begins to reproduce asexually and later sexually (Eyal et al. 1987; Eyal 1999; Ponomarenko et al., 2011). Airborne ascospores typically constitute the primary inoculum released from wheat debris (Suffert \& Sache, 2011; Morais et al., 2016). Pycnidiospores are splash-dispersed and are transmitted more locally infecting nearby leaves. They are the main secondary inoculum and drive the disease progress during the growing season (Kema et al. 1996; Hunter et al. 1999; Eyal 1999; McDonald \& Linde 2002; Ponomarenko et al. 2011). Under conducive conditions, this polycyclic pathogen can complete up to six asexual infection cycles during one growing season. Because of Z. tritici's mixed reproductive system, large population sizes and long-distance dispersal, its populations are extremely diverse (Linde et al., 2002; Hartmann et al., 2018).

Tunisia is a key durum wheat producer in the Mediterranean region but is also the largest per capita wheat consumer in the world (FAO, 2017). Wheat yields in Tunisia have steadily increased over the last century (Gharbi \& El Felah, 2013; El Felah \& Gharbi, 2014), but remain largely untapped despite their potential value (Latiri et al., 2010). The production is highly affected by drought and diseases and to compensate the deficit, the country has to import durum wheat in order to cover $25 \%$ of the local consumption (FAO, 2017; Gharbi \& El Felah, 2013). The main growing areas of durum wheat are located in the Northern part of the country under rain-fed conditions of a subhumid climate (Ammar et al., 2011), favourable for fungal diseases. Among these, STB poses an especially serious threat to Tunisian wheat production. Control of STB in Tunisia relies largely on fungicides and resistant cultivars. The use of chemical compounds has been adopted by Tunisian durum wheat growers at a slower pace as compared to bread wheat growers in Europe. With the first occurrences of strobilurin (Qol) resistance in Tunisia reported in 2012 (Boukef et al., 2012), current fungicide treatments in 
bioRxiv preprint doi: https://doi.org/10.1101/664078. this version posted April 15, 2020. The copyright holder for this preprint (which was not certified by peer review) is the author/funder. It is made available under a CC-BY 4.0 International license.

Ben M'Barek, Karisto, Abdedayem, Laribi, Cultivar mixtures for STB control Fakhfakh, Kouki, Mikaberidze, Yahyaoui

Tunisia rely mainly on DMIs (demethylation inhibitors) or mixtures of DMIs with strobilurins (Taher et al., 2014). At the same time, chemical control is costly and poses substantial risks to the environment and human health. Both factors give the farmers an incentive to reduce or avoid the use of fungicides.

The vast majority of commercial cultivars in Tunisia are highly susceptible to STB and new, STBresistant cultivars are released at a very slow rate (Ammar et al., 2011). The variety Karim, released in 1980, covers more than $60 \%$ of the durum wheat acreage (Ammar et al., 2011; Ben Hamouda et al., 2016; Rezgui et al., 2008; Ben Mohamed et al., 2000). Even though highly susceptible to STB, favourable agricultural properties combined with its relatively low gluten and low yellow flour content (Ammar et al., 2011) made it the farmer's favourite. In the last decade, a few STB-resistant cultivars were released in Tunisia, including 'Salim' that was registered in 2010. At the time of release, Salim showed resistance to STB (Gharbi \& El Felah, 2013), but it is gradually becoming more susceptible (Bel Hadj Chedli et al., 2018). In 2017, another promising variety, INRAT100 that contained Salim in its pedigree, was shown to be productive and resistant to several diseases including Septoria and Powdery mildew (Hammami \& Gharbi, 2018). Furthermore, among recently imported cultivars released in Tunisia, 'Monastir' is resistant to STB (SOSEM, 2018; Bel Hadj Chedli et al., 2018).

Currently, the two methods to control STB, fungicides and a few resistant cultivars, available to Tunisian farmers are not providing satisfactory levels of disease control. The country experiences serious recurrent epidemics of STB with yield losses reaching up to $40 \%$ (Berraies et al., 2014). Large part of the reason is that many farmers simply do not use either of the two control methods and neglect crop rotation practices. In addition, farmers often cannot afford fungicides. Those farmers who do use either of the two control methods exert a strong directional selection on pathogen populations. As a result, both fungicides and resistant cultivars are likely to rapidly lose efficacy against $Z$. tritici that has a high evolutionary potential (McDonald \& Linde, 2002). Thus, there is an urgent need to re-consider the way STB is controlled in Tunisia and devise management strategies that are not only efficient and sustainable, but also likely to be accepted by growers. Cultivar mixtures may prove to be such a strategy that is particularly well-suited to Tunisian conditions.

Despite the importance of durum wheat, the bulk of research on host resistance to STB has been conducted in bread wheat (Triticum aestivum) (Kollers et al., 2013; Brown et al., 2015; Karisto et al., 2018; Yates et al., 2019). At present, our understanding of genetics and molecular basis of STBresistance in durum wheat is limited. However, this situation may improve with the recent studies on 
Ben M'Barek, Karisto, Abdedayem, Laribi, Cultivar mixtures for STB control Fakhfakh, Kouki, Mikaberidze, Yahyaoui

Ethiopian durum wheat landraces (Kidane et al., 2017), Tunisian landraces (Aouini, 2018), and the publication of the fully assembled durum wheat genome (Maccaferri et al., 2019).

Similarly, cultivar mixtures for controlling STB have been studied in bread wheat but not in durum wheat (Mundt et al., 1995; Mille \& Jouan, 1997; Cowger \& Mundt, 2002; Mille et al., 2006; Gigot et al., 2013; Vidal et al., 2017). In most cases, STB severity in cultivar mixtures is moderately reduced compared to the expectation based on the severity in the pure stands, although Cowger \& Mundt (2002) did not observe a consistent pattern. In particular, Gigot et al. (2013) found that a susceptible cultivar was consistently protected in a mixture under low to moderate STB levels. Subsequent greenhouse experimentation (Vidal et al., 2017) and a modelling study (Vidal et al., 2018) have demonstrated the importance of canopy structure for the efficacy of a mixture.

The previous studies have not systematically investigated the effect of the proportion of different cultivars in the mixture (mixing proportion) on its efficacy against STB. This investigation is important both fundamentally and practically. Fundamentally, it provides a more robust and reliable measure of mixture efficacy across the whole range of mixing ratios, which may help to distinguish between different mechanisms of disease reduction in mixtures. From a practical perspective, growers may accept more easily mixtures that contain a small proportion of the resistant cultivar but still provide satisfactory disease control.

The number of different cultivars, or components, that comprise a mixture is another important parameter that affects the efficacy of disease control. Mille \& Jouan (1997) and Mille et al. (2006) considered mixtures with more than two components to control STB, but they only used equal proportions of cultivars in mixtures. For this reason, the proportion of the susceptible component varied between two-way, three-way, and four-way mixtures. This precluded consistent testing of whether more than one resistant component in a mixture further improves disease control, as predicted by epidemiological modelling (Mikaberidze et al., 2015).

The objectives of this study were to fill the gaps in current knowledge identified above. We investigate how the proportion of the cultivars in the mixture influences the efficacy of the mixture in controlling STB. Additionally, we determine whether a mixture that contains two resistant components improves the control of STB compared to a mixture with only one resistant component. 
Ben M'Barek, Karisto, Abdedayem, Laribi, Cultivar mixtures for STB control Fakhfakh, Kouki, Mikaberidze, Yahyaoui

\section{Materials and methods}

\section{Study area and experimental design}

Field experiment was conducted during 2017-2018 and 2018-2019 wheat growing seasons at the CRP Wheat Septoria Precision Phenotyping Platform -- experimental station of Kodia, which is located in the semi-arid region $\left(36^{\circ} 32^{\prime} 51.89^{\prime \prime} \mathrm{N}, 9^{\circ} 0^{\prime} 40.73^{\prime \prime E}\right.$, governorate of Jendouba, Tunisia, Figure $\left.1 \mathrm{~d}\right)$. The average annual rainfall in this area varies from 400 to $500 \mathrm{~mm}$ and the temperature usually ranges between $9.8^{\circ} \mathrm{C}$ (average minimum temperature) and $33^{\circ} \mathrm{C}$ (average maximum temperature). Daily temperature in the governorate of Jendouba and daily precipitation at the experimental station are shown in Figure S1 for both years of experiments. This region is considered to be a natural hot spot for STB disease.

For the first year, three commercial durum wheat cultivars (Karim, Salim and Monastir) were chosen based on their contrasting scores of resistance to STB, similar earliness and plant height. The susceptible cultivar Karim was originally selected from an introduced F4 bulk from CIMMYT. Cultivar Salim was selected from a cross made in Tunisia in 1993. Cultivar Monastir was imported from France and released in 2012 (SOSEM, 2018). In addition to the three cultivars and their mixtures, we included pure stands of INRAT100, a promising variety that has been registered in 2017 but is not yet released. There were 14 treatments in total: four pure stands, seven two-way mixtures and three three-way mixtures (Table 1). The mixtures with Karim contained always $25 \%, 50 \%$ or $75 \%$ of Karim, the rest being resistant cultivars. Each treatment was replicated three times in different plots.

For the second year the mixtures were changed, based on the first year's data. Salim was not included, but INRAT100 was used in mixtures with Karim. Karim was mixed with the two cultivars in one-way mixtures in proportions $0 \%, 50 \%, 75 \%, 87.5 \%$ and $100 \%$ (excluding $25 \%$ but adding $87.5 \%$, compared to the first year). There were 10 treatments in total: three pure stands, six one-way mixtures with Karim, and one 50-50 mixture of the resistant cultivars (Table 1). Each treatment was replicated four times in different plots. In the second year, all treatments were also replicated four times without inoculation but with fungicide sprays. This allowed us to have disease-free controls (see next section). 
Ben M'Barek, Karisto, Abdedayem, Laribi,

Fakhfakh, Kouki, Mikaberidze, Yahyaoui

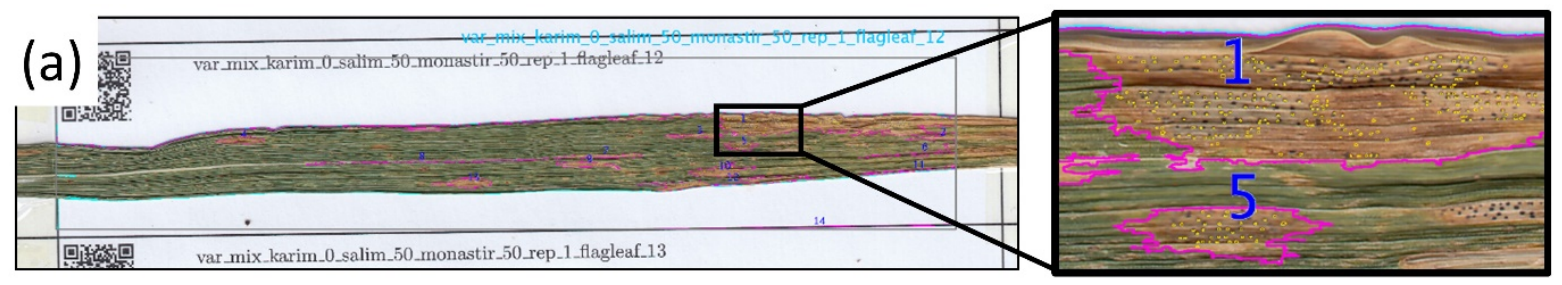

(b)

Year 1

\begin{tabular}{|c|c|c|c|c|c|c|c|c|c|c|c|c|c|c|}
\hline 1 & 2 & 3 & 4 & 5 & 6 & 7 & 8 & 9 & 10 & 11 & 12 & 13 & 14 & Rep 1 \\
\hline 14 & 9 & 4 & 11 & 1 & 7 & 3 & 5 & 6 & 8 & 13 & 2 & 12 & 10 & Rep 2 \\
\hline 4 & 8 & 7 & 12 & 6 & 14 & 1 & 11 & 2 & 9 & 10 & 13 & 5 & 3 & Rep 3 \\
\hline
\end{tabular}

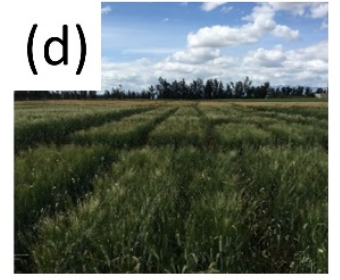

(c)

Year 2

\begin{tabular}{|c|c|c|c|c|}
\hline 2 & 4 & 7 & 6 & 1 \\
\hline 10 & 5 & 8 & 3 & 9 \\
\hline 5 & 1 & 9 & 2 & 3 \\
\hline 4 & 8 & 7 & 10 & 6 \\
\hline 2 & 10 & 8 & 6 & 5 \\
\hline 9 & 4 & 1 & 7 & 3 \\
\hline 10 & 9 & 8 & 7 & 6 \\
\hline 1 & 2 & 3 & 4 & 5 \\
\hline
\end{tabular}

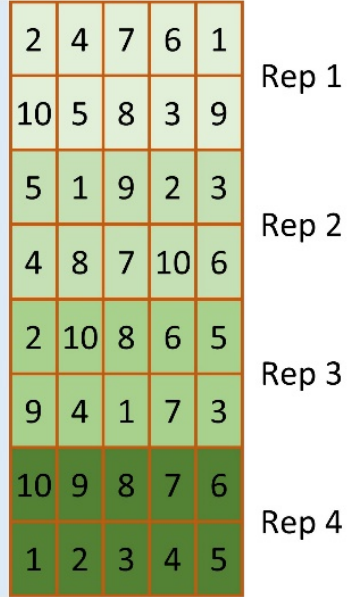

(e)

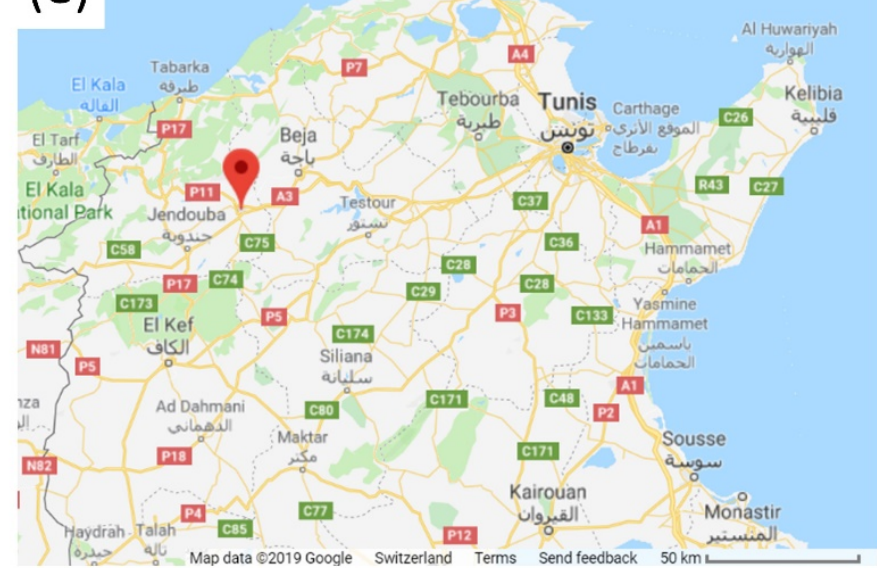

Figure 1. (a) Example of the automated leaf image analysis. Data is assigned to leaf label based on the QR-code. Cyan lines represent the leaf boundary, purple lines show lesion boundaries, and yellow circles represent detected pycnidia. Small lesions are not analysed. (b) Experimental field layout, the first year. Orange: experimental plots, numbers correspond to different treatments (Table 1), each of them replicated three times. (c) Experimental field layout, the second year. Orange: inoculated plots, green: uninoculated fungicide treated plots, numbers correspond to different treatments (Table 1), each of them replicated four times. (d) A photograph of the experimental plots. (e) Location of the experimental site. The map from Google. 
Ben M'Barek, Karisto, Abdedayem, Laribi, Cultivar mixtures for STB control Fakhfakh, Kouki, Mikaberidze, Yahyaoui

Table 1. Proportions of cultivars in pure stands, two-way and three-way mixtures planted in three replicates in 2017/2018 cropping season (Year 1 ) and in 2018/2019 cropping season (Year 2 ) at the Septoria Phenotyping Platform -- Kodia station (Bou Salem, Tunisia). Treatment numbers correspond to numbers in Fig. 1.

\begin{tabular}{|c|c|c|c|c|c|c|c|c|c|c|c|c|c|c|}
\hline \multirow{2}{*}{$\begin{array}{l}\text { Year } 1 \\
\text { Treatment \# }\end{array}$} & \multicolumn{4}{|c|}{ Pure stands } & \multicolumn{7}{|c|}{ Two-way mixtures } & \multicolumn{3}{|c|}{ Three-way } \\
\hline & 5 & 1 & 6 & 14 & 2 & 3 & 4 & 7 & 8 & 9 & 10 & 11 & 12 & 13 \\
\hline Karim (\%) & 100 & & & & 25 & 50 & 75 & 25 & 50 & 75 & & 25 & 50 & 75 \\
\hline Salim (\%) & & 100 & & & 75 & 50 & 25 & & & & 50 & 37.5 & 25 & 12.5 \\
\hline Monastir (\%) & & & 100 & & & & & 75 & 50 & 25 & 50 & 37.5 & 25 & 12.5 \\
\hline INRAT100 (\%) & & & & 100 & & & & & & & & & & \\
\hline
\end{tabular}

\begin{tabular}{lccc|ccccccc} 
Year 2 & \multicolumn{1}{c|}{ Pure stands } & \multicolumn{8}{|c}{ Two-way mixtures } \\
Treatment \# & 1 & 2 & 3 & 7 & 4 & 8 & 6 & 5 & 9 & 10 \\
\hline Karim (\%) & 100 & & & 50 & 75 & 87.5 & 50 & 75 & 87.5 & \\
INRAT100 (\%) & & \multirow{2}{*}{100} & & 50 & 25 & 12.5 & & & & 50 \\
Monastir (\%) & & & \multirow{2}{*}{100} & & & & 50 & 25 & 12.5 & 50 \\
\hline
\end{tabular}

\section{Preparation of plant and fungal material}

Seed of different cultivars were mixed in the drill according to the proportions of seed numbers corresponding to each treatment. Seed numbers were adjusted by weighing the seeds and using thousand-kernel-weight (TKW) of each cultivar. The seeds were sown on December 27, 2017 (first year), on plots of $5.25 \mathrm{~m}^{2}(3.5 \mathrm{~m} \times 1.5 \mathrm{~m})$ with a precision seeder at a density of 400 seeds $\mathrm{m}^{-2}$, and on November 8, 2018 (second year) on plots of $6 \mathrm{~m}^{2}(5 \mathrm{~m} \times 1.2 \mathrm{~m})$ at 350 seeds $\mathrm{m}^{-2}$ (densities comparable to common practices in the region). Subsequently, mean density of spikes was found to be 381 spikes $\mathrm{m}^{-2}$ in the first year and 297 spikes $\mathrm{m}^{-2}$ in the second year in inoculated plots and 300 spikes $\mathrm{m}^{-2}$ in the second year in fungicide treated plots. There were no differences in spike densities between treatments in the first (Kruskal-Wallis $p=0.93$ ) or the second year $(p=0.40)$, nor between inoculated and fungicide treated plots $(p=0.73)$. Spatial arrangement of treatments and replicates is shown in Figure 1a.

Standard agronomic practices were used to ensure adequate crop development. In the first year, herbicide treatment with a mixture of Traxos (1.2 L ha-1, Syngenta) and Zoom (180g ha-1, Syngenta) was applied on January 25, 2018, at tillering stage corresponding to GS13 [according to Zadoks scale (Zadoks et al., 1974)]. Manual and mechanical weeding was performed on March 19, 2018, (corresponding to stem elongation). Nitrogen fertilizer ammonium nitrate was applied three times at rates $120 \mathrm{~kg} \mathrm{ha}^{-1}, 150 \mathrm{~kg} \mathrm{ha}^{-1}$ and $150 \mathrm{~kg} \mathrm{ha}^{-1}$, on February 1, February 25, and April 1, 2018, respectively. No fungicides or insecticides were applied. 
bioRxiv preprint doi: https://doi.org/10.1101/664078. this version posted April 15, 2020. The copyright holder for this preprint (which was not certified by peer review) is the author/funder. It is made available under a CC-BY 4.0 International license.

Ben M'Barek, Karisto, Abdedayem, Laribi, Cultivar mixtures for STB control Fakhfakh, Kouki, Mikaberidze, Yahyaoui

In the second year, before sowing, the Roundup herbicide (Monsanto; active ingredient: Glyphosate $\left.360 \mathrm{~g} \mathrm{~L}^{-1}\right)$ was applied with a rate of $3 \mathrm{~L} \mathrm{ha}^{-1}$. Manual weeding was done on March 25, 2019. Nitrogen fertilizer ammonium nitrate was applied three times with a rate of $150 \mathrm{~kg} \mathrm{ha}^{-1}$ : December 20, 2018 (GS30), February 14, 2019 (GS32) and March 25, 2019 (GS40). No insecticides were applied. Five fungicide treatments were applied for the treated-control plots to ensure little or no disease. The first fungicide application was done on January 22, 2019 (Product Opus, Stima; Epoxiconazol 125g L-1, 0.75 $\mathrm{L} \mathrm{ha}^{-1}$ ), the second one on February 27, 2019 (Cherokee, Syngenta; Cyproconazole 40 $\mathrm{g} \mathrm{L}^{-1}$,

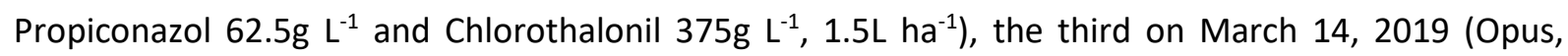
Stima; 0.75 $\mathrm{L} \mathrm{ha}^{-1}$ ), the fourth on April 11 (Ogam, Stima; Epoxiconazol $125 \mathrm{~g} \mathrm{~L}^{-1}$ and Kresoxim-methyl $125 \mathrm{~g} \mathrm{~L}^{-1}, 0.7 \mathrm{~L} \mathrm{ha}^{-1}$ ) and fifth on May 3, 2019 (Ogam, Stima; 0.7L ha-1).

The inoculum of Z. tritici was produced in the wheat Septoria platform laboratory according to Ferjaoui et al. (2015) with slight modifications. Six isolates were obtained from infected leaves of durum wheat collected in the same region and used to prepare the inoculum. The isolates were grown for 6 to 8 days on potato dextrose agar. Inoculum was prepared in $250 \mathrm{~mL}$ yeast-glucose liquid medium ( $30 \mathrm{~g}$ glucose, $10 \mathrm{~g}$ yeast in $1 \mathrm{~L}$ of water). The flasks were inoculated with fresh pieces of $Z$. tritici colonies from agar plates and incubated in a rotary shaker at $100 \mathrm{rpm}$, at $15^{\circ} \mathrm{C}$ for $5-7$ days. The inoculum concentration was adjusted to $10^{6}$ spores $\mathrm{mL}^{-1}$ and the resulting spore suspension was supplemented with $0.1 \%$ of Tween 20 (Merck, UK) prior to inoculation in the field. Approximately $700 \mathrm{~mL}$ of the spore suspension was applied per plot using a sprayer (Efco AT800, Italy). In the first year, wheat plants were inoculated three times, on February 27, March 9, and March 20 2018, corresponding to tillering stage (from GS13 to GS26). In the second year, similarly three inoculation were performed on December 12, December 26, and January 10 (GS13 to GS26).

\section{Disease assessment}

Disease levels were assessed two times in both years: at $t_{1}$ on flag-1 leaves (the leaf below the flag leaf) and at $t_{2}$ on flag leaves [first year $t_{1}$ on 22 April (GS 61) and $t_{2}$ on 9 May (GS 75); second year $t_{1}$ on April 17 (GS 73) and $t_{2}$ on April 25 (GS 75)]. From each inoculated plot, 24 leaves were collected without considering their infection status and in a sparse uniform random manner. The collector bias was minimized by a stringent collection protocol: first, a spike was chosen at random without looking at leaves and avoiding edges of the plot. Only after that selection, the leaf below this spike was collected. During the collection, the leaves were placed in paper envelopes and kept on ice in a thermo-insulated box. After collection, the leaves were taken to the lab and kept at $4-5^{\circ} \mathrm{C}$ for one to three days before inspection. The leaves were then inspected visually for the presence of pycnidia as a sign of STB infection. The absence of pycnidia was interpreted as absence of STB, even if necrotic 
Ben M'Barek, Karisto, Abdedayem, Laribi, Cultivar mixtures for STB control Fakhfakh, Kouki, Mikaberidze, Yahyaoui

lesions were visible. In this way, STB incidence was estimated as the proportion of infected leaves in each plot. After visual examination, the infected leaves were mounted on paper sheets and scanned, as described by Karisto et al. (2018). The uninoculated fungicide treated plots were inspected visually and confirmed to be healthy.

Scanned leaf images were analysed using ImageJ software (Schindelin et al., 2015) with the help of the automated image analysis macro originally developed by Stewart and McDonald (2014) and further improved by Stewart et al. (2016) and Karisto et al. (2018). The program quantified necrotic leaf area and counted pycnidia on each infected leaf as measures of conditional severity of STB, i.e. the severity only on infected leaves. From this raw data, three quantities were computed: (i) the percentage of leaf area covered by lesions (PLACL), (ii) the density of pycnidia per $\mathrm{cm}^{2}$ of lesion area ( $\left.\rho_{\text {lesion }}\right)$, and (iii) the density of pycnidia per $\mathrm{cm}^{2}$ of total leaf area ( $\left.\rho_{\text {leaf }}\right)$. The three quantities characterise different aspects of conditional severity of STB. PLACL measures the damage induced by the pathogen to the host, Plesion measures the degree of pathogen reproduction within the host, and $\rho_{\text {leaf }}$ is the product of PLACL and $\rho_{\text {lesion }}$ that incorporates both host damage and pathogen reproduction (Karisto et al., 2018). To estimate the full, unconditional severity, each of the three measures of conditional severity were multiplied by disease incidence of the corresponding plot.

At each four time points, 200 leaf images were selected to test the accuracy of the automated image analysis. They were first inspected qualitatively for lesion and pycnidia detection errors (i.e. substantial underestimation or overestimation). After excluding erroneous leaves, the accuracy of automated counting of pycnidia was evaluated by counting pycnidia manually on 20 leaves at each time point and comparing the manual counts to the estimates from the image analysis. The leaves for both qualitative and quantitative evaluation were selected with a stratified random sampling based on 10 approximately equally sized classes for pycnidia counts to ensure a satisfactory coverage of the entire distribution of pycnidia counts. To quantify the accuracy of automated pycnidia counts with respect to manual counts, we calculated the concordance correlation coefficient (Lin 1989), Pearson's and Spearman's correlation coefficients, and the average error of automated pycnidia counts.

\section{Yield assessment}

In all plots, the grain yield $\left(\mathrm{kg} \mathrm{ha}^{-1}\right)$ and the TKW (g) were measured. When the plants in all plots had reached physiological maturity (Zadoks et al., 1974), the entire plot area was harvested (29 June 2018 and 24 June 2019). Grain yield was calculated by determining the total grain weight in the harvested area $\left(\mathrm{kg} \mathrm{ha}^{-1}\right)$. TKW was estimated by weighing 500 kernels. The effect of disease on yield 
Ben M'Barek, Karisto, Abdedayem, Laribi,

Cultivar mixtures for STB control

Fakhfakh, Kouki, Mikaberidze, Yahyaoui

was determined in the second year's data by subtracting the yield of each inoculated plot from the yield of corresponding fungicide-treated plot.

\section{Statistical analysis}

Treatments were compared to each other based on the three measures of the full STB severity described above: PLACL, $\rho_{\text {lesion, }}$ and $\rho_{\text {leaf. }}$ From now on, we will use these three measures of severity to refer to full severity, unless specified otherwise. The data was analysed using Python programming language (version 3.5.2, https://www.python.org), using the open-source packages SciPy (version 1.0.1; Jones et al., 2001), NumPy (version 1.14.3) and matplotlib (version 2.2.3). The source code developed for the analysis will be available from the Dryad Digital Repository.

Presence of global differences between medians of treatments was tested by Kruskal-Wallis test implemented as scipy.stats.kruskal function. Post-hoc comparisons were conducted with multiple Dunn's test with the false discovery rate correction (Benjamini-Hochberg) using the library scikit_posthocs (version 0.3.8). Separate comparisons were first conducted for each of four time points. Due to the limited number of replicates, strong conclusions cannot be drawn from individual treatments and time points. Hence, after performing the comparisons within individual mixtures separately, all data were normalised based on the mean of susceptible treatment for each variable within the time point, and then pooled based on the proportion of the susceptible cultivar Karim in the mixture. The analysis of the pooled data was conducted in a similar fashion as the analysis within the individual treatment groups described above. The aim of this analysis was to identify general patterns of how disease levels depend on the proportion of a resistant cultivar in the mixture.

Finally, we tested for mixture effects using the following procedure. Expected levels of disease and yield were calculated for each mixture based on the average of the two pure stands $(100 \%$ susceptible and $0 \%$ susceptible), weighted according to their proportions in the mixture (linear expectation). Note that in three-way mixtures the resistant cultivars were always in equal proportions and thus $0 \%$ susceptible corresponds to $1: 1$ mixture of the resistant cultivars Salim and Monastir (Table 1). The deviations from the linear expectation were calculated for each plot. Then the treatments were pooled based on the percentage of the susceptible cultivar as above and Wilcoxon signed rank test (scipy.stats.wilcoxon) was used to determine if those deviations from linear expectation were symmetric around zero. Comparison of treatments with respect to yield was based on TKW and grain yield. 
Ben M'Barek, Karisto, Abdedayem, Laribi, Cultivar mixtures for STB control Fakhfakh, Kouki, Mikaberidze, Yahyaoui

\section{Results}

\section{Overview of the dataset}

Septoria tritici blotch severity was assessed at two time points on all 42 plots in the first year and 40 plots in the second. In total, approximately 3900 leaves were inspected for the presence of the disease. Total number of infected leaves included in the image analysis for measuring severity was 3074 (646 leaves at $t_{1} 2018 ; 638$ at $t_{2} 2018 ; 887$ at $t_{1} 2019 ; 903$ at $t_{2} 2019$ ). Based on the qualitative check, 70 leaves were excluded from the dataset. The most common reasons for exclusion were overestimation of lesion area due to insect damage and overestimation of pycnidia counts due to dirt on leaves. Overall, the pycnidia counts by image analysis were consistent with the manual counting in the test set of 80 leaves (106 000 pycnidia detected by macro vs 98000 manually counted, concordance correlation coefficient $=0.98 ; r_{\text {spearman }}=0.96, p=2 \times 10^{-43} ;$ Fig. S2). The final data set based on 3004 leaf images will be available from the Dryad Digital Repository.

We observed considerable disease levels at each time point. Both the disease and the yield levels were higher in the second year: mean pycnidia density per unit leaf area ( $\rho_{\text {leaf }}$ ) on flag leaves $\left(t_{2}\right)$ was $24 \mathrm{~cm}^{-2}$ in 2018 and $103 \mathrm{~cm}^{-2}$ in $2019\left(p=6 \times 10^{-9}\right)$, grain yield in 2018 was $2500 \mathrm{~kg} \mathrm{ha}^{-1} \mathrm{vs} 5600 \mathrm{~kg} \mathrm{ha}$ ${ }^{1}$ in 2019 ( $p=7 \times 10^{-15}$, Fig. 2a, b). Disease levels were generally higher in the pure stands of the susceptible cultivar (Karim) than in the pure stands of the resistant cultivars (Salim, Monastir and INRAT100) or mixtures, consistently between all time points (see supplementary figures for different variables and time points: Figs. S3-S4 for pure stands, Figs. S5-S8 for individual mixtures). Overall degree of disease control in mixtures relative to susceptible pure stands in shown in Figure $2 d$, e.

\section{Disease reduction in the mixtures}

Analysis of disease levels in durum wheat mixtures revealed a general pattern where the pure stand of the susceptible cultivar Karim had the highest disease levels and treatments including a resistant cultivar had significantly lower disease levels, except for the smallest proportion of $12.5 \%$ of resistant cultivar (Figure $2 \mathrm{~d}, \mathrm{e}$ ). Introducing only $25 \%$ of a resistant component to the susceptible pure stand was enough to suppress the disease levels significantly by $48 \%$ compared to the susceptible pure stands ( $p=0.0198$; see also Figs. S9-S10 for combined performance of mixtures within each time point). In the first year, mixtures with only $25 \%$ of a resistant component suppressed the disease down to levels not significantly different from the resistant pure stand (Fig. S9f). These trends were generally true for all three measures of severity, both two-way and three-way mixtures and the four time points with a few exceptions (see supplementary Figures). 
Ben M'Barek, Karisto, Abdedayem, Laribi,

Cultivar mixtures for STB control

Fakhfakh, Kouki, Mikaberidze, Yahyaoui

For yield measures, there was neither a clear increase nor decrease when the proportion of the susceptible cultivar Karim was decreased from $100 \%$ to zero. Possible explanation of this observation is that in pure stands, the susceptible cultivar Karim did not have consistently lower or higher yield compared to the pure stands of the resistant cultivars (Fig 2c, no significant differences).

(a)

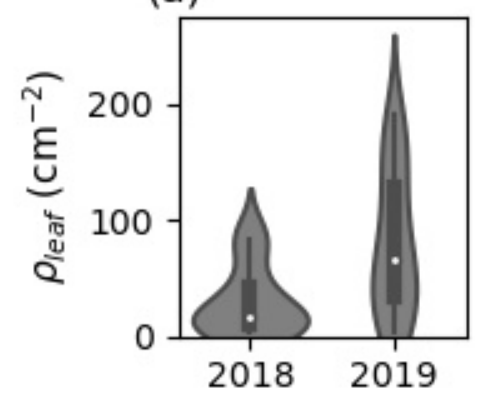

(b)

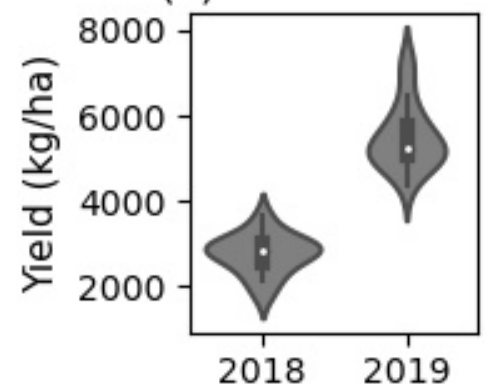

(c)

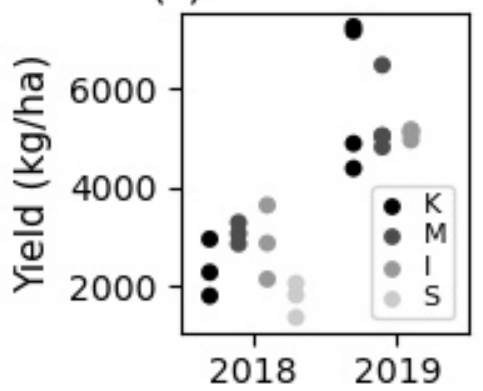

(d)

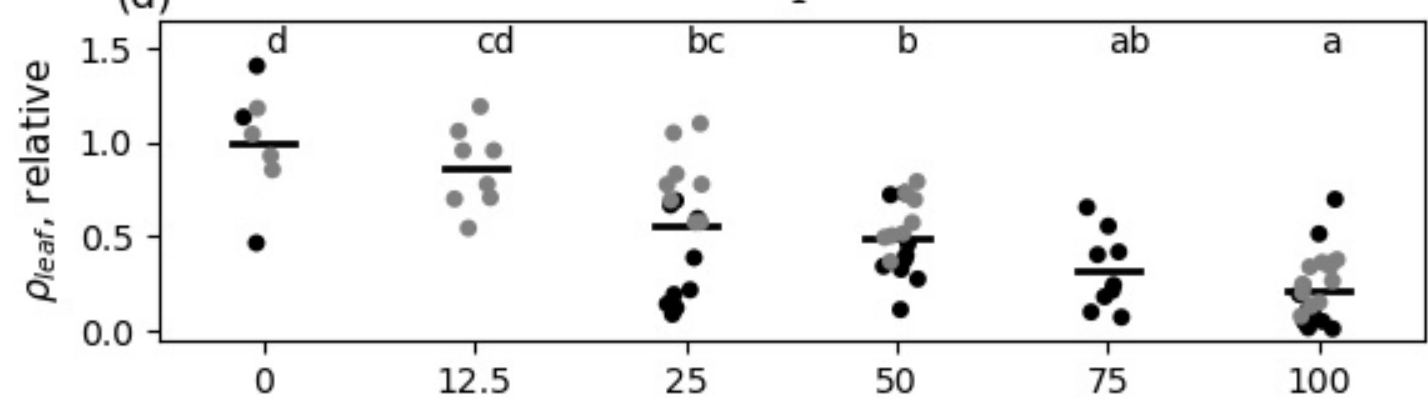

(e) $\mathrm{t}_{2}$

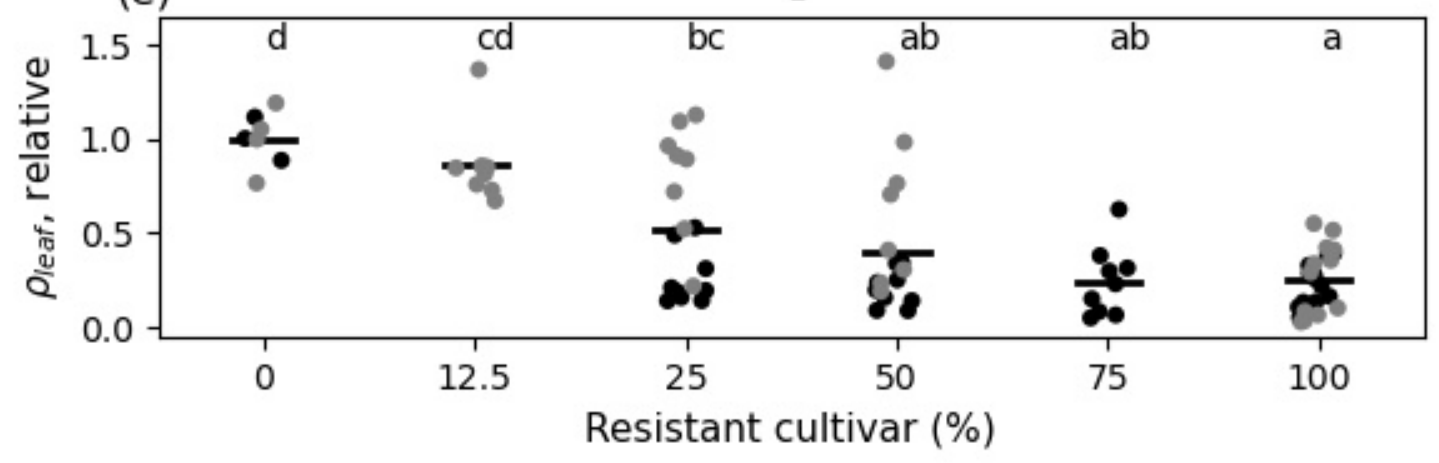

Figure 2. STB severity and yield patterns. (a) Distribution of STB severity (pleaf, plot means) in the repeated treatments in the first year (2018) and the second year (2019). Disease levels were higher in the second year ( $p=0.015$, for repeated treatments). (b) Grain yield in the repeated treatments in both years. Yield was higher in the second year $\left(p=5.7 \times 10^{-7}\right)$. (c) Grain yield in pure stands. No differences between cultivars within each year $(p=0.10$ and $p=0.87$ for the first and the second year, respectively). Letters in legend refer to first letter of the cultivar name. (d, e) Pattern of STB severity at $t_{1}$ and $t_{2}$, respectively (pleaf, plot means) in the combined data of two years (black: 2018, grey: 2019), including all treatments, pooled based on the percentage of resistant cultivar. Values relative to the susceptible treatments in each time point. Black bars show mean severity. Mixtures with $0 \%$ or $12.5 \%$ had no significant difference, but $25 \%, 50 \%$ and $75 \%$ had lower severity than $0 \%$ (only susceptible) and were not different from each other. 
Ben M'Barek, Karisto, Abdedayem, Laribi,

Cultivar mixtures for STB control

Fakhfakh, Kouki, Mikaberidze, Yahyaoui

\section{Mixture effects}

If each component of a mixture performed independently of other components, then the overall disease severity in a mixed stand would be given by the sum of disease severities in corresponding pure stands weighted by the mixing proportions. However, mixture effects may improve the overall performance compared to the sum of individual components. To determine the magnitude of mixture effects, we compared disease severity and yield observed in mixed stands to linear expectations based on measurements in pure stands. Comparing mixture treatments to linear expectations of each treatment group (In 2018 Karim-Salim, Karim-Monastir, and three-way; in 2019 Karim-Monastir and Karim-INRAT100) showed that adding $25 \%$ of resistance to susceptible Karim resulted in significant beneficial mixture effect on disease levels ( $\left.\rho_{\text {leaf }}\right)$, i.e. the severity was lower than expected $(p=0.0099)$. The mixture effect was strongest in the treatment with $25 \%$ of resistant component (mean effect $=-30 \%$-points) but significant also for $50 \%$ and $75 \%$ of resistance $(-23 \%$ points, $p=0.0129$ and $-21 \%$-points, $p=0.0284$, respectively. Fig 3 ). See Figure $S 11$ for mixture effect tests on other variables, and Figures S12-S13 for the tests on individual time points separately. Mixture effects were generally stronger and more common in the first year than in the second. We observed beneficial mixture effect on yield in $25 \%$ resistant mixture in the first year (Fig. S12g) but not in the pooled data of two years (Fig. S11c, d).

\section{Effect of the number of resistant components in the mixture}

To determine whether adding a second resistant cultivar to a two-way mixture of a resistant and a susceptible cultivars leads to a further reduction of disease, we compared the STB severity and yield in two- and three-way mixtures at a constant proportion of the susceptible cultivar Karim (Figs. S14S17). For example, at $75 \%$ of Karim, we compared the three-way mixture of $75 \% / 12.5 \% / 12.5 \%$ proportions of Karim/Salim/Monastir with each of the corresponding two-way mixtures $75 \% / 25 \%$ Karim/Salim and 75\%/25\% Karim/Monastir. In some cases, three-way mixtures had a slightly higher STB severity than both corresponding two-way mixtures; in other cases, three-way mixtures had an intermediate severity with respect to corresponding two-way mixtures. Interestingly, in none of the cases, a mixture with two resistant components exhibited a significant reduction in STB severity or increase in yield with respect to both corresponding mixtures with only one resistant cultivar.

\section{Cultivar mixtures combined with fungicides}

The fungicide treated plots yielded more than the inoculated, not fungicide treated plots. Mean effect on yield was $1500 \mathrm{~kg} \mathrm{ha}^{-1}(\mathrm{SD}=790)$ and on thousand kernel weight $7.4 \mathrm{~g}(\mathrm{SD}=5.7)$. There were no differences between treatments in the effect of fungicides for either measure of yield. Moreover, 
bioRxiv preprint doi: https://doi.org/10.1101/664078. this version posted April 15,2020 . The copyright holder for this preprint (which was not certified by peer review) is the author/funder. It is made available under a CC-BY 4.0 International license.

Ben M'Barek, Karisto, Abdedayem, Laribi, Cultivar mixtures for STB control Fakhfakh, Kouki, Mikaberidze, Yahyaoui

when pooling the treatments based on percentage of resistant cultivar, we found no significant differences (Fig. S18). All fungicide treated plots were fully protected from fungal diseases by the intensive spray program applied.

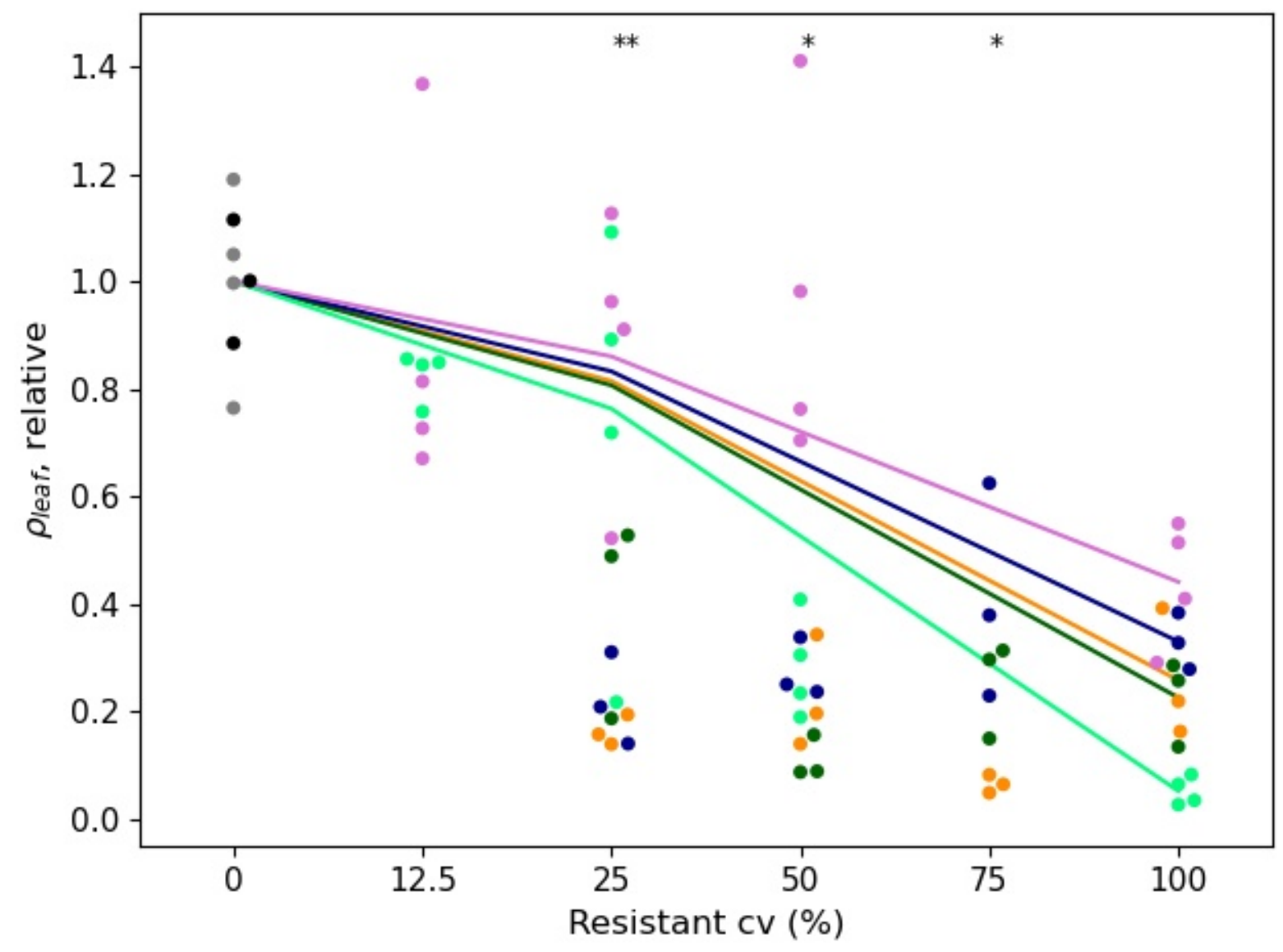

Figure 3. Non-linear mixture effects on STB severity at $t_{2}$ of both years ( $\rho$ leaf, plot means, relative to mean of the susceptible treatment). Lines show linear expectations for each group of treatments (note non-uniform scale of $x$-axis). Dark blue, yellow and green dots and lines represent Karim-Salim, Karim-Monastir and three-way mixtures, respectively, in the first year. Light green and pink represent Karim-Monastir and Karim-INRAT100 mixtures, respectively, in the second year. Black dots: susceptible cultivar Karim in the first year, grey dots: Karim in the second year. Significant mixture effects, i.e. lower severity than expected, are indicated with asterisks: * for $p<0.05$ and ${ }^{* *}$ for $p<0.01$. 
bioRxiv preprint doi: https://doi.org/10.1101/664078. this version posted April 15, 2020. The copyright holder for this preprint (which was not certified by peer review) is the author/funder. It is made available under a CC-BY 4.0 International license.

Ben M'Barek, Karisto, Abdedayem, Laribi, Cultivar mixtures for STB control Fakhfakh, Kouki, Mikaberidze, Yahyaoui

\section{Discussion}

Our analyses show that introducing only $25 \%$ of a disease-resistant cultivar into a pure stand of a susceptible cultivar provides a substantial reduction in disease levels. To measure the severity of Septoria tritici blotch in the field, we used a novel, high-throughput method based on digital analysis of leaf images. This method allowed us to acquire a large dataset that exceeds previous studies on host mixtures with respect to accuracy and precision (Stewart and McDonald, 2014). The method also allowed us to accurately measure numbers of pycnidia on wheat leaves, thereby allowing to quantify pathogen reproduction within the host, which was not possible using conventional visual assessment.

The observed pattern matches qualitatively with the findings of Jeger et al. (1981b), who investigated the effect of cultivar mixtures on the epidemic development of Septoria nodorum blotch (SNB) caused by the necrotrophic fungal pathogen Parastagonospora nodorum (Oliver et al., 2012; Quaedvlieg et al., 2013). Jeger et al. (1981b) mixed an SNB-resistant with an SNB-susceptible cultivar at different proportions and reported that the $25 \% / 75 \%$ resistant/susceptible mixture "reduced disease levels effectively to that found in the resistant pure stand" - similarly to what we observed in the first year. This similarity in outcomes for $P$. nodorum and $Z$. tritici suggests that there may be a general underlying mechanism. Since the two pathogens are largely similar in terms of their epidemiology, infection biology and population genetic structure, further studies on cultivar mixtures affecting these and other similar pathogens could establish whether this pattern holds more generally and to determine which characteristics of the pathogen are responsible for this effect.

Short-range splash dispersal that dominates the spread of both $P$. nodorum and $Z$. tritici may be one such characteristic. The disease reduction pattern described above may be favouring the barrier effect rather than the dilution effect as the dominant mechanism of disease reduction. Note however, that the pattern was nearly linear in second year, favouring dilution. This is because the dilution effect is expected to cause a gradual decrease in the level of disease when the proportion of resistant plants is increased, as predicted for example by the discrete-time population model of Jeger et al., (1981a). In contrast, the barrier effect may result in an abrupt, threshold-like drop in the level of disease at a certain critical proportion of the resistant cultivar in the mixture. At this critical proportion, the connectivity between susceptible plants is disrupted and their population is subdivided into isolated patches. Our data from the second year suggests that $12.5 \%$ of the resistant component in the mixture is not enough for achieving this critical proportion and substantial reduction of the disease. 
bioRxiv preprint doi: https://doi.org/10.1101/664078. this version posted April 15, 2020. The copyright holder for this preprint (which was not certified by peer review) is the author/funder. It is made available under a CC-BY 4.0 International license.

Ben M'Barek, Karisto, Abdedayem, Laribi, Cultivar mixtures for STB control Fakhfakh, Kouki, Mikaberidze, Yahyaoui

Similar fragmentation phenomena have been studied extensively in ecology in the context of habitat loss and fragmentation by adapting the conceptual framework of percolation theory (Bascompte \& Sole, 1996; Swift \& Hannon, 2010), but have not received attention in studies of cultivar mixtures. This mechanism is expected to be of importance in pathogens with sufficiently short range dispersal (for example, splash dispersal in Z. tritici and P. nodorum on wheat and Rhynchosporium secalis on barley, or dispersal of many soil-borne pathogens), but be less prominent in air-borne pathogens such as those causing rust and mildew diseases. Theoretical prediction of the critical proportion of resistant plants that causes fragmentation of susceptible plant population requires quantitative characterisation of pathogen's dispersal under field conditions, but such measurements in $Z$. tritici and $P$. nodorum are still lacking.

Adding a second resistant cultivar to a two-way mixture making it a three-way mixture provided no additional reduction of disease compared to two-way mixtures of resistant and susceptible cultivars, contrary to the theoretical prediction (Mikaberidze et al., 2015). A possible explanation for this discrepancy could be that either (i) the pathogen population did not possess a sufficient degree of specialisation with respect to the two resistant cultivars and therefore the pathogen population have not been partitioned enough between the two resistant cultivars to result in a measurable reduction of disease. Alternatively, (ii) the resistance of the two cultivars has a largely overlapping genetic basis. Both of these scenarios violate the assumptions of the model (Mikaberidze et al., 2015).

Although we did not observe a significant reduction of disease when a second resistant component was added to two-way mixtures, this can have an important effect on the adaptation of pathogen population to host resistances. If the resistance in the two resistant cultivars is conferred by different genes, then a three-way mixture is expected to impose less selection on the pathogen population compared to a two-way mixture with the same proportion of the susceptible component, in this way extending the durability of host resistances.

The differences in the performance of cultivar mixtures in disease reduction between years are likely to reflect remarkably differing weather conditions. The second year, 2019, was exceptionally good for wheat yield in Tunisia, which was reflected in our data. These conditions were favourable also for STB leading to higher levels of disease severity in the second year. Possible other sources of variability include length of the growing season and timings of inoculation and leaf collections (Fig. S1). A curious detail in our experiment is that the mixture effects for disease control and yield were stronger in the first year, i.e. the year of lower yield. Similarly, Gigot et al. (2013) observed that susceptible cultivar was consistently protected in mixture under low to moderate disease pressure. If further experiments would confirm consistency of this pattern, the mixtures would be particularly 
Ben M'Barek, Karisto, Abdedayem, Laribi, Cultivar mixtures for STB control Fakhfakh, Kouki, Mikaberidze, Yahyaoui

useful for farmers during "bad" years and hence provide a convenient protection against extreme losses. Long-term experiments would be desirable for establishing benefits of cultivar mixtures in variable conditions.

To conclude, our study (together with the study of Jeger et al. ,1981b) contributes to establishing of a practically useful rule of thumb, according to which adding $25 \%$ of resistant plants to the susceptible pure stand provides substantial protection from disease, in the best case as strong as the resistant pure stand. Such mixtures may have an important advantage with respect to planting resistant pure stands: they are more likely to be used by growers if the susceptible cultivar is agronomically superior compared to the resistant cultivar and/or is generally more accepted by growers. A followup study will need to consider whether these mixtures would behave differently or similarly under natural STB infection and in different environments as well as to examine the durability of the disease control provided by a mixture over time.

\section{Acknowledgements}

This work was supported by the "CRP WHEAT Tunisia Septoria Precision Phenotyping Platform". PK and AM gratefully acknowledge financial support from the Swiss National Science Foundation through the Ambizione grant PZOOP3_161453. The authors have no conflicts of interest to declare. 
Ben M'Barek, Karisto, Abdedayem, Laribi, Cultivar mixtures for STB control

Fakhfakh, Kouki, Mikaberidze, Yahyaoui

\section{References}

Ammar K, Gharbi MS, and Deghais M, 2011. Wheat in Tunisia. In: Bonjean AP, Angus WJ, van Ginkel, $\mathrm{M}$, eds. The world wheat book: A history of wheat breeding. Vol. 2. Lavoisier, Paris, France. 443-463

Aouini L, 2018. Durum wheat and septoria tritici blotch: genes and prospects for breeding. Wageningen, The Netherlands: Wageningen University, PhD thesis.

Bascompte J, Sole RV, 1996. Habitat Fragmentation and Extinction Thresholds in Spatially Explicit Models. Journal of Animal Ecology 65, 465-473

Bel Hadj Chedli R, Ben M'Barek S, Yahyaoui A, Kehel Z, Rezgui S, 2018. Occurrence of Septoria tritici blotch (Zymoseptoria tritici) disease on durum wheat, triticale, and bread wheat in Northern Tunisia. Chilean Journal of Agricultural Research 78(4), 559-568.

Ben Hamouda M, Ben Youssef S, Bedhiaf S, Annabi M, Draief Z, and Gharbi MS, 2016. Status of agricultural innovations, innovation platforms, and innovations investment. Tunisia. 2015 PARI project country report: Republic of Tunisia. Forum for Agricultural Research in Africa (FARA), Accra, Ghana.

Ben Mohamed L, Rouaissi M, Sebei A, Hamza S, Harrabi M, 2000. Effet du génotype, de la date de semis, de la fertilisation azotée et potassique et des fongicides sur le développement de Septoria tritici. In: Royo C, Nachit M, Di Fonzo N, Araus JL eds. Durum wheat improvement in the Mediterranean region: New challenges. Zaragoza, Spain: CIEHAM, 350-356.

Berraies S, Gharbi MS, Rezgui S, Yahyaoui A, 2014. Estimating grain yield losses caused by septoria leaf blotch on durum wheat in Tunisia. Chilean Journal of Agricultural Research 74(4), 432-437.

Borg J, Kiær LP, Lecarpentier C, Goldringer I, Gauffreteau A, Saint-Jean S, Barot S, Enjalbert J, 2018. Unfolding the potential of wheat cultivar mixtures: A meta-analysis perspective and identification of knowledge gaps. Field Crops Research 221, 298-313.

Boukef S, 2012. Structure des populations, spécificité parasitaire et évaluation de la résistance aux fongicides chez Zymoseptoria tritici, agent de la septoriose du blé en Tunisie. Institut National Agronomique de Tunisie. pp : 1-102.

Brown JKM, Chartrain L, Lasserre-Zuber P, Saintenac C, 2015. Genetics of resistance to Zymoseptoria tritici and applications to wheat breeding. Fungal Genet Biol. 79, 33-41. 
Ben M'Barek, Karisto, Abdedayem, Laribi, Cultivar mixtures for STB control Fakhfakh, Kouki, Mikaberidze, Yahyaoui

Civitello DJ, Cohen J, Fatima H et al., 2015. Biodiversity inhibits parasites: Broad evidence for the dilution effect. Proc. Natl. Acad. Sci. 112, 8667-8671.

Cowger C, Mundt CC, 2002. Effects of wheat cultivar mixtures on epidemic progression of Septoria tritici blotch and pathogenicity of Mycosphaerella graminicola. Phytopathology 92, 617-623.

Duncan KE, Howard RJ, 2000. Cytological analysis of wheat infection by the leaf blotch pathogen Mycosphaerella graminicola. Mycol. Res. 104, 1074-1082.

El Felah M, Gharbi MS, 2014. Les céréales en Tunisie: Historique, contraintes de développement et perspectives. Journée National sur la valorisation des résultats de la Recherche dans le domaine des Grandes Culture, 1-7.

Eriksen L., Shaw MW, Østergård H, 2001. A model of the effect of pseudothecia on genetic recombination and epidemic development in populations of Mycosphaerella graminicola. Phytopathology 91, 240-248.

Eyal Z, 1999. The Septoria tritici and Stagonospora nodorum Blotch Diseases of Wheat. European Journal of Plant Pathology 105, 629-641.

Eyal Z, Scharen AL, Prescott JM, Van Ginkel M, 1987. The septoria diseases of wheat: concepts and methods of disease management: CIMMYT. Mexico, DF, 52-70.

FAO. 2017. Country fact sheet on food and agriculture policy trends. Socio-economic context and role of agriculture. Food and Agriculture Policy Decision Analysis (FAPDA). Rome, Italy: FAO. Available at http://www.fao.org/3/a-i7738e.pdf.

Ferjaoui S, Ben M'Barek S, Bahri B, Slimane RB, Hamza S, 2015. Identification of resistance sources to septoria tritici blotch in old durum wheat germplasm applied for the analysis of the Zymoseptoria tritici-durum wheat interaction. Journal of Plant Pathology 97, 471-481

Finckh MR, Gacek ES, Goyeau H, Lannou C, Merz U, Mundt CC, Munk L, Nadziak J, Newton AC, de Vallavieille-Pope C, Wolfe MS, 2000. Cereal variety and species mixtures in practice, with emphasis on disease resistance. Agronomie 20, 813-37.

Finckh MR, Wolfe MS, 1997. The use of biodiversity to restrict plant diseases and some consequences for farmers and society. In: Jackson LE, eds. Ecology in Agriculture. San Diego, US: Academic Press, 199-233. 
Ben M'Barek, Karisto, Abdedayem, Laribi, Cultivar mixtures for STB control Fakhfakh, Kouki, Mikaberidze, Yahyaoui

Finckh MR, Wolfe MS, 2006. Diversification strategies. In: Cooke BM, Jones DG, Kaye B, eds. The epidemiology of plant diseases. Dordrecht: Springer Netherlands, 269-307.

Fones HN, Eyles CJ, Kay W, Cowper J, Gurr SJ, 2017. A role for random, humidity-dependent epiphytic growth prior to invasion of wheat by Zymoseptoria tritici. Fungal Genetics and Biology 106, 51-60.

Garrett KA, Mundt CC, 1999. Epidemiology in mixed host populations. Phytopathology 89, 984-990.

Gharbi MS, El Felah M, 2013. Les Céréales en Tunisie: plus d'un siècle de recherche variétale". Annales de l'INRAT, Numéro Spécial- Centenaire de l'INRAT (1913-2013) 86, 45-68.

Gigot C, Saint-Jean S, Huber L et al., 2013. Protective effects of a wheat cultivar mixture against splash-dispersed septoria tritici blotch epidemics. Plant Pathology 62, 1011-1019.

Hammami R, Gharbi MS, 2018. Contribution of breeding program to the sustainability of durum wheat production. Journal of New Sciences 59, 3799-3805.

Hartmann FE, McDonald BA, Croll D, 2018. Genome-wide evidence for divergent selection between populations of a major agricultural pathogen. Molecular ecology 27, 2725-2741.

Huang C, Sun Z, Wang H, Luo Y, Ma Z, 2012. Effects of wheat cultivar mixtures on stripe rust: A metaanalysis on field trials. Crop Protection 33, 52-58.

Hunter T, Coker R, Royle D, 1999. The teleomorph stage, Mycosphaerella graminicola, in epidemics of septoria tritici blotch on winter wheat in the UK. Plant pathology 48, 51- 57.

Jeger MJ, Griffiths E, Jones DG, 1981a. Disease progress of nonspecialised fungal pathogens in intraspecific mixed stands of cereal cultivars I. Models. Annals of Applied Biology 98, 187-98.

Jeger MJ, Jones DG and Griffiths E, 1981b. Disease progress of non-specialised fungal pathogens in intraspecific mixed stands of cereal cultivars II. Field experiments. Annals of Applied Biology 98, 199210.

Jones E, Oliphant E, Peterson P, and others, 2001. SciPy: Open Source Scientific Tools for Python. [http://www.scipy.org/] Accessed 6 May 2019.

Karisto P, Dora S, Mikaberidze A, 2019. Measurement of infection efficiency of a major wheat pathogen using time-resolved imaging of disease progress. Plant Pathology 68, 163-172. 
Ben M'Barek, Karisto, Abdedayem, Laribi, Cultivar mixtures for STB control Fakhfakh, Kouki, Mikaberidze, Yahyaoui

Karisto P, Hund A, Yu K et al., 2018. Ranking quantitative resistance to septoria tritici blotch in elite wheat cultivars using automated image analysis. Phytopathology 108, 568-81.

Kema GHJ, Sayoud R, Annone JG, van Silfhout CH, 1996. Genetic variation for virulence and resistance in the wheat-Mycosphaerella graminicola pathosystem II. Analysis of interactions between pathogen isolates and host cultivars. Phytopathology 86, 213-220.

Kidane YG, Hailemariam BN, Mengistu DK, Fadda C, Pè ME, Dell'Acqua M., 2017. Genome-Wide Association Study of Septoria tritici Blotch Resistance in Ethiopian Durum Wheat Landraces. Front. Plant Sci. 8, 1586.

King KC, Lively CM, 2012. Does genetic diversity limit disease spread in natural host populations? Heredity 109, 199-203.

Kiær LP, Skovgaard IBM, Østergård H,2009. Grain yield increase in cereal variety mixtures: A metaanalysis of field trials. Field Crops Research 114, 361-373.

Kollers S, Rodemann B, Ling J et al., 2013. Genetic architecture of resistance to Septoria tritici blotch (Mycosphaerella graminicola) in European winter wheat. Mol. Breed. 32, 411-423.

Latiri K., Lhomme JP, Annabi M, Setter TL, 2010. Wheat production in Tunisia: Progress, inter-annual variability and relation to rainfall. European Journal of Agronomy 33, 33-42.

Linde CC, Zhan J, McDonald BA, 2002. Population structure of Mycosphaerella graminicola: From lesions to continents. Phytopathology 92, 946-955.

Lucas JA, Hawkins NJ, Fraaije BA, 2015. The Evolution of Fungicide Resistance. Advances in Applied Microbiology 90, 29-92.

Maccaferri M, Harris NS, Twardziok SO, et al., 2019. Durum wheat genome highlights past domestication signatures and future improvement targets. Nature Genetics 51, 885-895.

Marshall R, Kombrink A, Motteram J, Loza-Reyes E, Lucas J, Hammond-Kosack KE, 2011. Analysis of two in planta expressed LysM effector homologs from the fungus Mycosphaerella graminicola reveals novel functional properties and varying contributions to virulence on wheat. Plant physiology 156, 756-769.

McDonald BA, Linde C, 2002. Pathogen population genetics, evolutionary potential, and durable resistance. Annu. Rev. Phytopathol. 40, 349-379. 
Ben M'Barek, Karisto, Abdedayem, Laribi, Cultivar mixtures for STB control Fakhfakh, Kouki, Mikaberidze, Yahyaoui

McDonald BA, Mundt CC, 2016. How knowledge of pathogen population biology informs management of Septoria tritici blotch. Phytopathology 106, 948-955.

Mehrabi R, 2006. Signaling pathways involved in pathogenicity and development of the fungal wheat pathogen Mycosphaerella graminicola. PhD thesis, Wageningen University, The Netherlands.

Mikaberidze A, McDonald BA, Bonhoeffer S, 2015. Developing smarter host mixtures to control plant disease. Plant Pathology 64, 996-1004.

Mille B, Fraj MB, Monod H, de Vallavieille-Pope C, 2006. Assessing four-way mixtures of winter wheat cultivars from the performances of their two-way and individual components. European Journal of Plant Pathology 114, 163-173.

Mille B, Jouan B, 1997. Influence of varietal associations on the development of leaf and glume blotch and brown leaf rust in winter bread wheat. Agronomie 17, 247-251.

Morais D, Sache I, Suffert F, Laval V, 2016. Is the onset of septoria tritici blotch epidemics related to the local pool of ascospores? Plant Pathology 65, 250-260.

Mundt CC, 2002. Use of multiline cultivars and cultivar mixtures for disease management. Annu. Rev. Phytopathology 40, 381-410.

Mundt CC, Brophy LS, Schmitt MS, 1995. Choosing crop cultivars and cultivar mixtures under low versus high disease pressure: A case study with wheat. Crop Protection 14, 509-515.

Mundt CC, Hayes PM, Schön CC, 1994. Influence of barley variety mixtures on severity of scald and net blotch and on yield. Plant pathology 43, 356-361.

Newton AC, Begg GS, Swanston JS, 2009. Deployment of diversity for enhanced crop function. Ann Appl Biol. 154, 309-322.

Newton AC, Ellis RP, Hackett CA, Guy DC, 1997. The effect of component number on Rhynchosporium secalis infection and yield in mixtures of winter barley cultivars. Plant Pathology 46, 930-8.

Oliver RP, Friesen TL, Faris JD, Solomon PS, 2012. Stagonospora nodorum: from pathology to genomics and host resistance. Annu. Rev. Phytopathol. 50, 23-43.

Ostfeld RS, Keesing F, 2012. Effects of Host Diversity on Infectious Disease. Annu. Rev. Ecol. Evol. Syst. 43, 157-82. 
Ben M'Barek, Karisto, Abdedayem, Laribi,

Cultivar mixtures for STB control

Fakhfakh, Kouki, Mikaberidze, Yahyaoui

Ponomarenko A, Goodwin S, Kema G, 2011. Septoria tritici blotch (STB). The Plant Health Instructor. DOI: 10.1094/PHI-I-2011-0407-01

Quaedvlieg W, Verkley GJM, Shin H-D, Barreto, RW, Alfenas AC, Swart WJ, Groenewald JZ, Crous PW, 2013. Sizing up Septoria. Stud. Mycol. 75, 307-390.

Rezgui S, Fakhfakh MM, Boukef S, Rhaiem A, Chérif M, Yahyaoui AH, 2008. Effect of common cultural practices on septoria leaf blotch disease and grain yield of irrigated durum wheat. Tunisian Journal of Plant Protection 3, 59-68.

Schindelin J, Rueden CT, Hiner MC, Eliceiri KW, 2015. The ImageJ Ecosystem: An Open Platform for Biomedical Image Analysis. Molecular Reproduction and Development 82, 518-529.

Smithson JB, Lenné JM, 1996. Varietal mixtures: a viable strategy for sustainable productivity in subsistence agriculture. Annals of Applied Biology 128,127-158.

SOSEM, Société des Semences sélectionnées, 2018. http://sosem.tn/en/produits

Steinberg G, 2015. Cell biology of the wheat pathogen Zymoseptoria tritici. Fungal Genetics and Biology 79, 17-23.

Stewart EL, Hagerty CH, Mikaberidze A, Mundt CC, Zhong Z, McDonald BA, 2016. An improved method for measuring quantitative resistance to the wheat pathogen Zymoseptoria tritici using highthroughput automated image analysis. Phytopathology 106,782-788.

Stewart, EL, and McDonald, BA. 2014. Measuring quantitative virulence in the wheat pathogen Zymoseptoria tritici using high-throughput automated image analysis. Phytopathology 104, 985-992.

Suffert F, Sache I, 2011. Relative importance of different types of inoculum to the establishment of Mycosphaerella graminicola in wheat crops in north-west Europe. Plant Pathology 60, 878-889.

Swift TL, Hannon SJ, 2010. Critical thresholds associated with habitat loss: a review of the concepts, evidence, and applications. Biol. Rev. 85, 35-53.

Taher K, Graf S, Fakhfakh MM, Ben-Haj Salah H, Yahyaoui A, Rezgui S, Nasraoui B, Stammler G, 2014. Sensitivity of Zymoseptoria tritici isolates from Tunisia to pyraclostrobin, fluxapyroxad, epoxiconazole, metconazole, prochloraz and tebuconazole. Journal of Phytopathology 162, 442-448. 
Ben M'Barek, Karisto, Abdedayem, Laribi, Cultivar mixtures for STB control Fakhfakh, Kouki, Mikaberidze, Yahyaoui

USDA FAS, United States Department of Agriculture, Foreign Agricultural Service, 2019.Tunisia Grain and Feed Annual - Bumper Crop within Reach. GAIN Report Number: TS1929. [https://gain.fas.usda.gov/Recent\%20GAIN\%20Publications/Grain\%20and\%20Feed\%20Annual Tunis Tunisia 3-28-2019.pdf]. Accessed 7 May 2019.

de Vallavieille-Pope C, Belhaj Fraj M, Mille B, Meynard J-M, 2006. Les associations de variétés: accroître la biodiversité pour mieux maitriser les maladies. Dossiers de l'Environnement de I'INRA 30, 101-109. https://prodinra.inra.fr/record/23009.

Vidal T, Boixel A-L, Durand B, de Vallavieille-Pope C, Huber L, Saint-Jean S, 2017. Reduction of fungal disease spread in cultivar mixtures: impact of canopy architecture on rain-splash dispersal and on crop microclimate. Agricultural and Forest Meteorology 246, 154-161.

Vidal T, Gigot C, Vallavieille-Pope C, Laurent H, Saint-Jean S, 2018. Contrasting plant height can improve the control of rain-borne diseases in wheat cultivar mixture: Modelling splash dispersal in 3D canopies. Annals of Botany 121, 1299-1308.

Wolfe MS, 1985. The current status and prospects of multiline cultivars and variety mixtures for disease resistance. Annual Review of Phytopathology 23, 251-273.

Wolfe MS, Baresel JP, Desclaux D. et al., 2008. Developments in breeding cereals for organic agriculture. Euphytica 163, 323-346.

Yates S, Mikaberidze A, Krattinger S, et al., 2019. Precision phenotyping reveals novel loci for quantitative resistance to septoria tritici blotch in European winter wheat. Plant Phenomics, 3285904.

Zadoks JC, Chang TT, Konzak CF, 1974. A decimal code for the growth stages of cereals. Weed Research 14, 415-421.

Zhan J, McDonald BA, 2004. The interaction among evolutionary forces in the pathogenic fungus Mycosphaerella graminicola. Fungal Genetics and Biology 41, 590-599.

Zhan J, Mundt CC, McDonald BA, 1998. Measuring immigration and sexual reproduction in field populations of Mycosphaerella graminicola. Phytopathology 88, 1330-1337. 


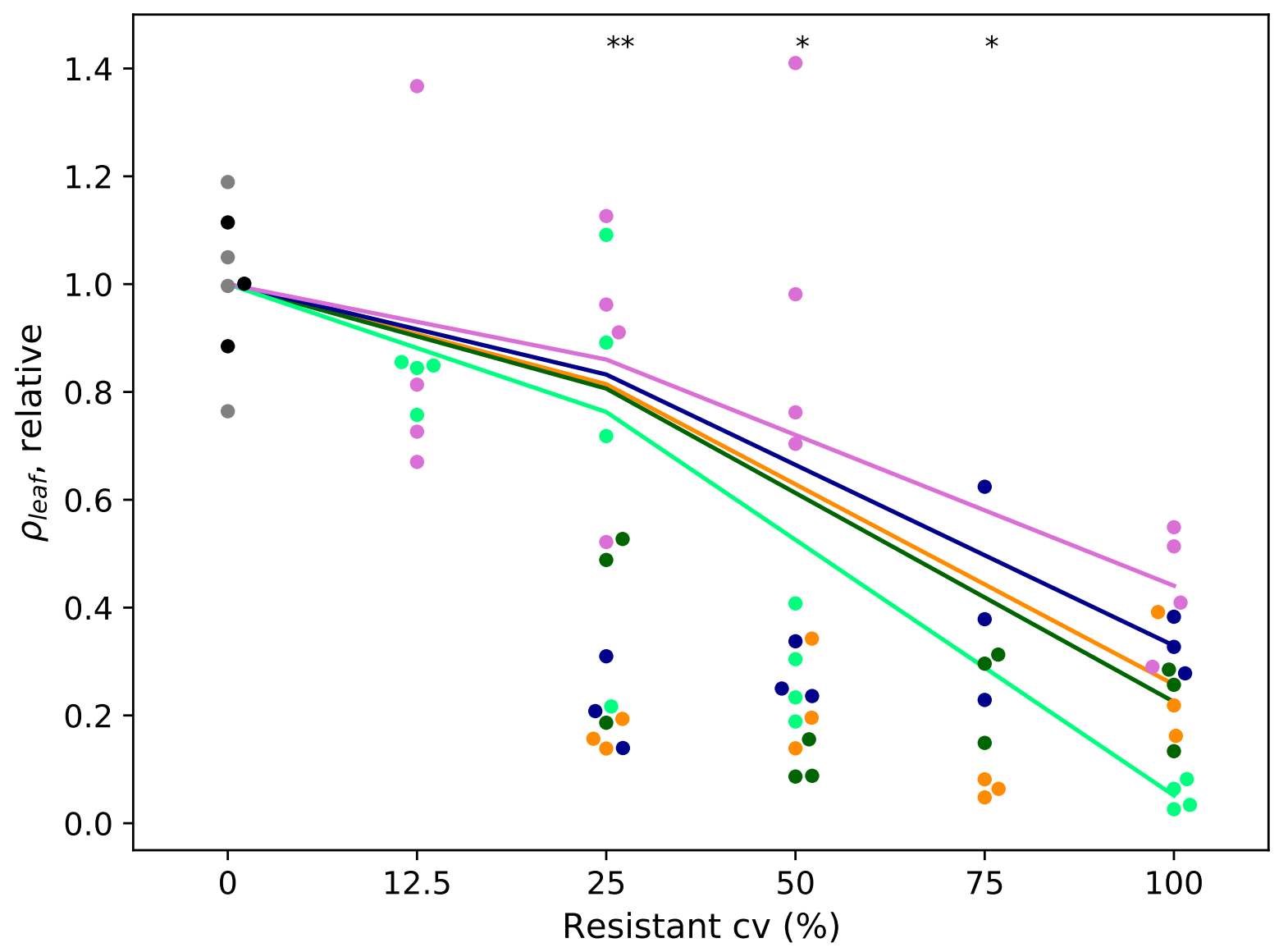


(a)

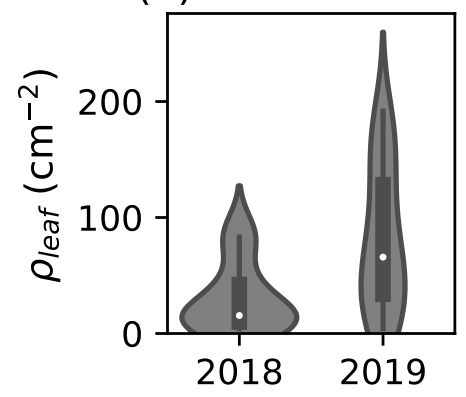

(d)

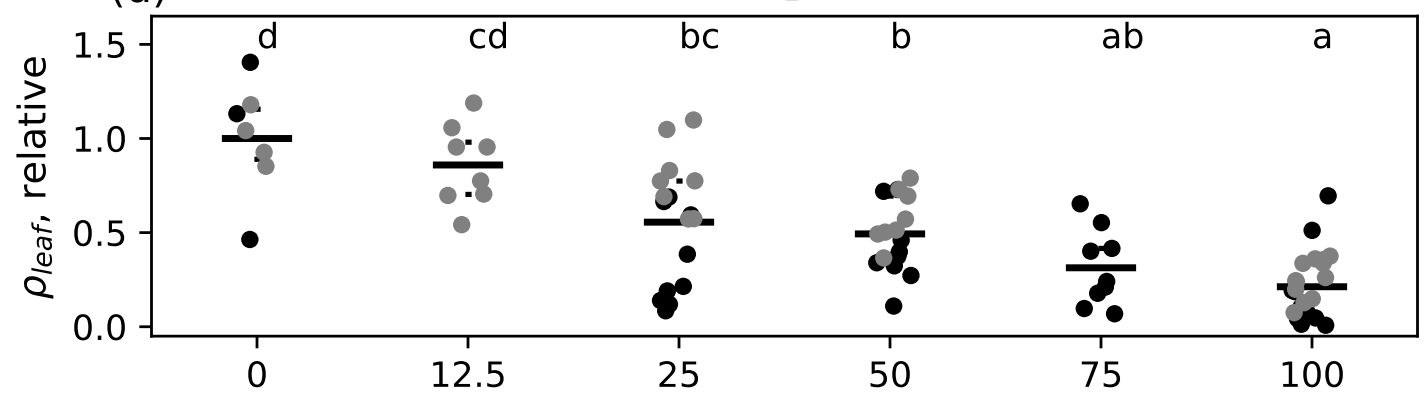

(e)

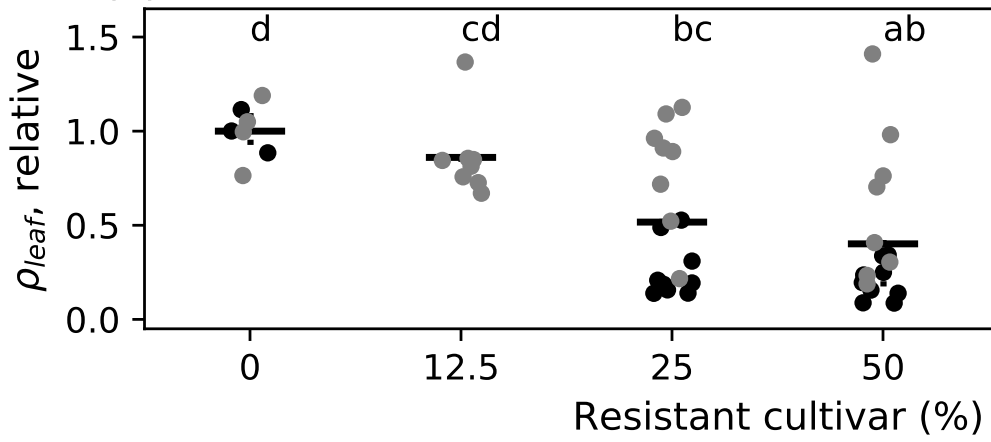

(c)

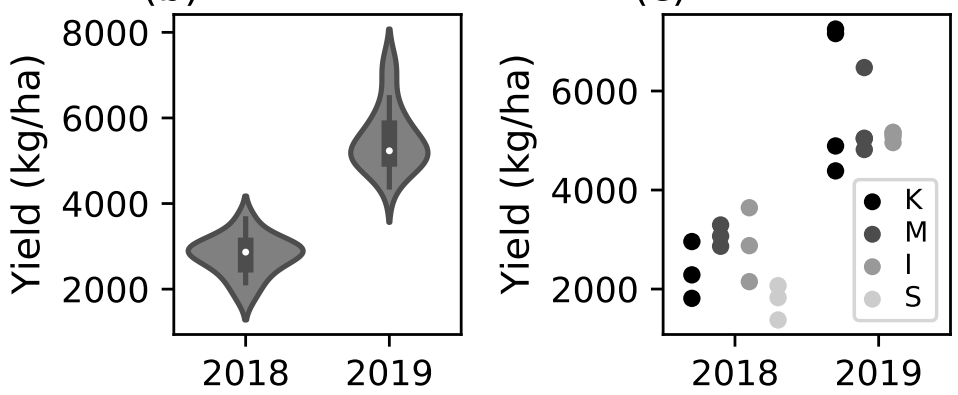

$t_{1}$ 